Res. Popul. Ecol. (1977) 19, 87-98.

\title{
ERADICATION OF THE MELON FLY, DACUS CUCURBITAE, FROM KUME IS., OKINAWA WITH THE STERILE INSECT RELEASE METHOD
}

\author{
Osamu IWAHASHI \\ Okinawa Prefectural Agricultural Experiment Station, 4-222, \\ Sakiyama, Naha 903, Japan
}

The first successful demonstration of the sterile insect release method (SIRM) was against the screw-worm, Cochliomyia hominivorax, which was eradicated from Curacao Is. in 1954 (BAumhover et al., 1955). This fly was also eradicated from the Florida Peninsula with the same method in 1959 (LACHAnce et al., 1967). The melon fly, Dacus cucurbitae, on Rota Is. and the oriental fruit fly, D. dorsaris, on Guam Is. were eradicated with SIRM till 1963 (STEINER, 1965). Since then many attempts have been made in a number of countries to control or eradicate insect pests with this method. However, it is our opinion that there has been no successful eradication of an insect pest with the SIRM among these trials, except for temporal annihilations or cases where large numbers of sterile insects were released to eradicate a pest just after its accidental introduction in small numbers. Thus there are still many problems which need to be solved to develop this unique method for practical eradications of noxious insects. Of particular importance in the SIRM are reliable procedures for obtaining precise information on the population parameters of wild and released insects.

In 1972, the Japanese Ministry of Agriculture and the Okinawa Prefectural Government started a large scale experimental project to eradicate the melon fly, Dacus cucurbitae CoquilletT, with SIRM from the $58.5 \mathrm{~km}^{2}$ island of Kume, Okinawa. This was the first attempt to implement SIRM in Japan. For this purpose, a mass-rearing facility and an irradiation facility were established on Ishigaki Is., which is about $300 \mathrm{~km}$ southwest of Naha, the island of Okinawa, and in Naha, respectively (Fig. 1).

Before sterile-fly releases were started, the population density of the wild melon flies on Kume Is. was estimated with the mark-release-recapture method (ITô et al., 1974). The number of mature wild males in the peak season (November) of 1972 was estimated to be ca. 2.5 million. Meanwhile the production capacity of the mass-rearing facility just before the beginning of sterile insect releases was only 1-1.5 million.

In order to reduce the size of the wild fly population prior to the mass releases of sterile insects, control of the melon fly population was attempted by aerial distribution of cotton strings saturated with a solution of cue-lure (97\%) and naled $(3 \%)$, and with ground sprays of a mixture of protein hydrolyzate and technical malathion (IWAHASHi et al., 1975). Possibly due to these treatments, which were 


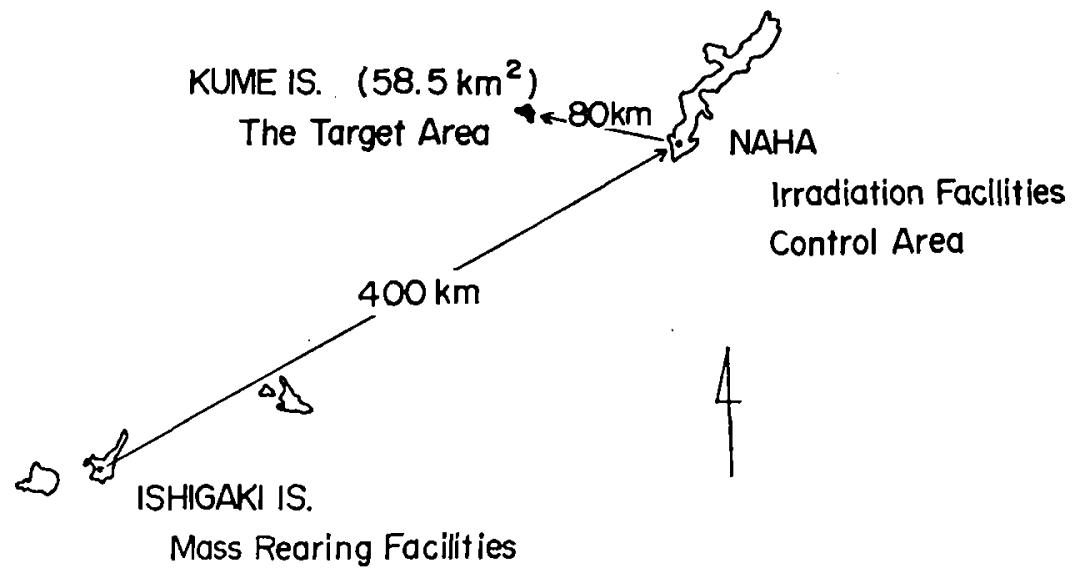

Fig. 1. Map of the Ryukyus. The three islands of Ishigaki,

Okinawa and Kume are shown; other islands are omitted.

applied from November, 1972 to January, 1975, the density of the melon fly population in January, 1975, just before the beginning of mass-releases was estimated to be about $5 \%$ of the peak density. The fly density on Kume Is. at the bottom of yearly fluctuations was lower in early spring of 1974 (when the intensity of control was not so strong) than in 1975 (see Fig.4) but as the population trends in Naha, the control area, and Kume Is. were remarkably different at the end of 1974 , we can consider that the decrease in fly density in autumn of 1974 was mainly due to the effect of control practices.

\section{Methods}

Fly pupae to be sterilized and released were reared in the mass-rearing facility on Ishigaki Is. (NAKAmoRI et al., 1975, KAKIHANA et al., 1975, NAKAMORI et al., 1976). They were transported weekly by air to Naha using a specially designed container and irradiated at a dose of $6-7 \mathrm{kR}$ with a cobalt-60 source, 2 or 3 days before adult eclosion. The pupae were then air-shipped to Kume Is. and marked with a fluorescent dye (Whitex SKC ${ }^{\mathrm{k}}$, Satan Yellow ${ }^{\mathrm{N}}$, or Blaze Orange ${ }^{\mathrm{k}}$ ) at a rate of 4 to $8 \mathrm{~g}$ per 100,000 pupac. Pupae in specially designed release buckets were placed in 170 release points distributed over the island. The mean distance between points was about $600 \mathrm{~m}$. Pupae were usually left in release buckets until the next release in order to determine the rate of emergence.

To evaluate the ratio of sterile to wild males in the field, 50 monitor traps (plastic traps baited with cue-lure and naled) were distributed over the island. These traps were examined twice a month, and the melon flies caught were brought to the laboratory. Heads of these flies were carefully crushed on filter paper with a glass rod dipped in acetone, and the filter paper was examined under an ultraviolet lamp (2537 $\AA$ or $3650 \AA / 100$ V) for fluorescent marks. 
Initially we had planned to release 1 million pupae per week, which was near the maximum number of pupae we could produce in our mass-rearing facility at that time. Although the ratio of marked (sterile) to unmarked (normal) males in the monitor traps, $M / U$, had decreased from March to July, 1975, there was no sign of decrease in the percent egg-hatch in Kume Is. as compared with the control area at Naha, thus we made some modifications in our mass-rearing system to increase the number of pupae up to 2 million per week. After March 1976, we attempted to further increase the number of pupae released up to 4 million per week to accelerate the eradication process. The actual number of pupae released exceeded 3.5 million per week in May, 1976.

Other modifications made in our SIRM project after September, 1975 were as follows:

1. To decrease the mortality of teneral adults due to predation, the design of release buckets was modified to discourage predators.

2. The number of release points was increased from 170 to 200 , in order to concentrate sterile flies in localities where host plants were abundant.

3. In June, 1976 the so-called Taiwan-type monitor trap was replaced with the Steiner-type (STEINER, 1957), the bottom of which was covered with a saran-net to prevent the occurrence of a natural fluorescence in trapped flies due to decomposition of the insects (see below).

To evaluate the effect of sterile-fly releases on the hatchability of eggs, female flies were netted in fields on Kume Is. These females were reared individually in small plastic containers and eggs were collected with an artificial oviposition device (see Iwahashi et al., 1976). Eggs deposited in the device were placed on moistened filter paper in petri dishes and kept for 3 days at a constant temperature of $27^{\circ} \mathrm{C}$ after which the rate of egg-hatch was determined. Bi-monthly examinations of 5 monitor traps and collections of females were also made in Naha, which was the control area where no releases were made.

Infestation levels were checked monthly by collection of fruits of a wild cucurbit plant, Bryonopsis laciniosa, from many localities on Kume Is. More than 2,000 fruits were examined every month during the experimental period, except April and July, 1975. Fruits with apparent infestations or punctures were dissected within 2 or 3 days after they were collected and eggs or larvae found were recorded. Fruits containing unhatched eggs were recorded as uninfested. The remaining fruits were kept on moistened sand in plastic containers for 2 or 3 weeks at ambient temperatures to allow pupation and emergence of insects which had previously been overlooked.

\section{RESUlts}

Fig. 2 presents the results of sterile-fly releases on Kume Is. from February, 1975 to December, 1976. Open circles in Fig. 2-a indicate the number of sterilized 


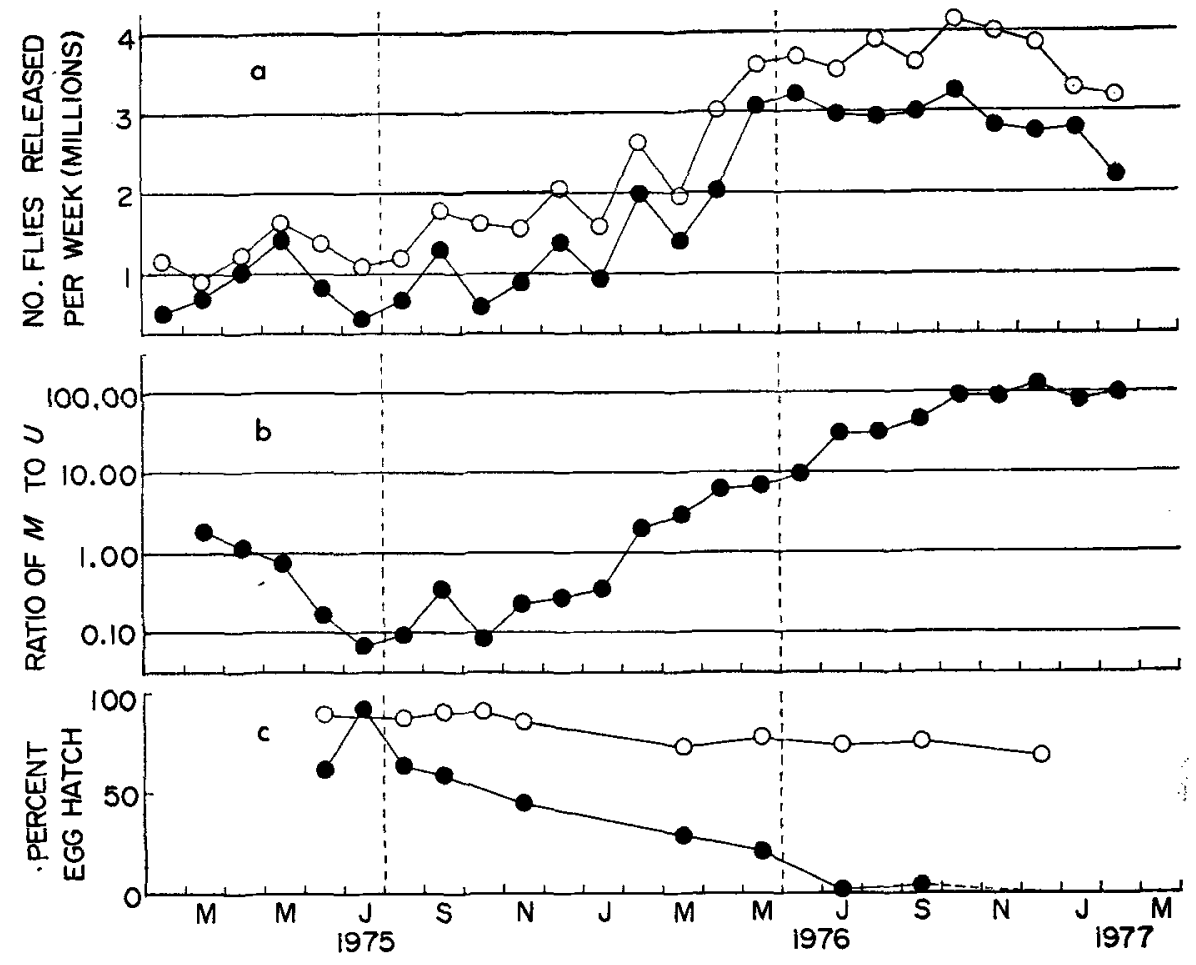

Fig. 2. Results of sterile insect releases on Kume Is, from February, 1975 to February 1977. Fig. 2-a shows the average number of sterilized pupae released per week (open circles) and estimated number of flies emerged (solid circles). Fig. 2-b shows the monthly ratio of marked $(M)$ to unmarked males $(U)$ caught in 50 monitor traps on Kume Is. Fig. 2-c shows the hatchability of eggs laid by female melon flies collected on Kume Is. (solid circles) and Naha, the control area (open circles).

pupae released per week, and solid circles the number of adults emerged, which was estimated from the number of pupae released and the rate of successful emergence of sampled pupae, Fig. $2-\mathrm{b}$ shows the change in the ratio of marked to unmarked flies, $M / U$, caught in 50 monitor traps. No marked fly was captured in February and the $M / U$ ratio was 1.83 in March, 1975. But the ratio decreased thereafter in spite of the increased numbers of sterile flies released. This was probably due to a seasonal rise in the population density of wild flies which exceeded the increase in numbers of released flies. The melon fly population usually decreases on Kume Is. during June and July (Iwahashi et al., 1975), but further decreases in the $M / U$ ratio were observed even in these months. One reason for this may have been due to an underestimation of the ratio, because since June, determination of marked flies with an ultraviolet lamp became difficult due to the frequent occurrence of a green natural fluorescence in captured flies. This natural fluorescence was attributed to the decomposition of dead flies in Taiwan-type traps due to warm and humid conditions. Since all flies with only very faint fluorescence were recorded as 'unmarked' the 


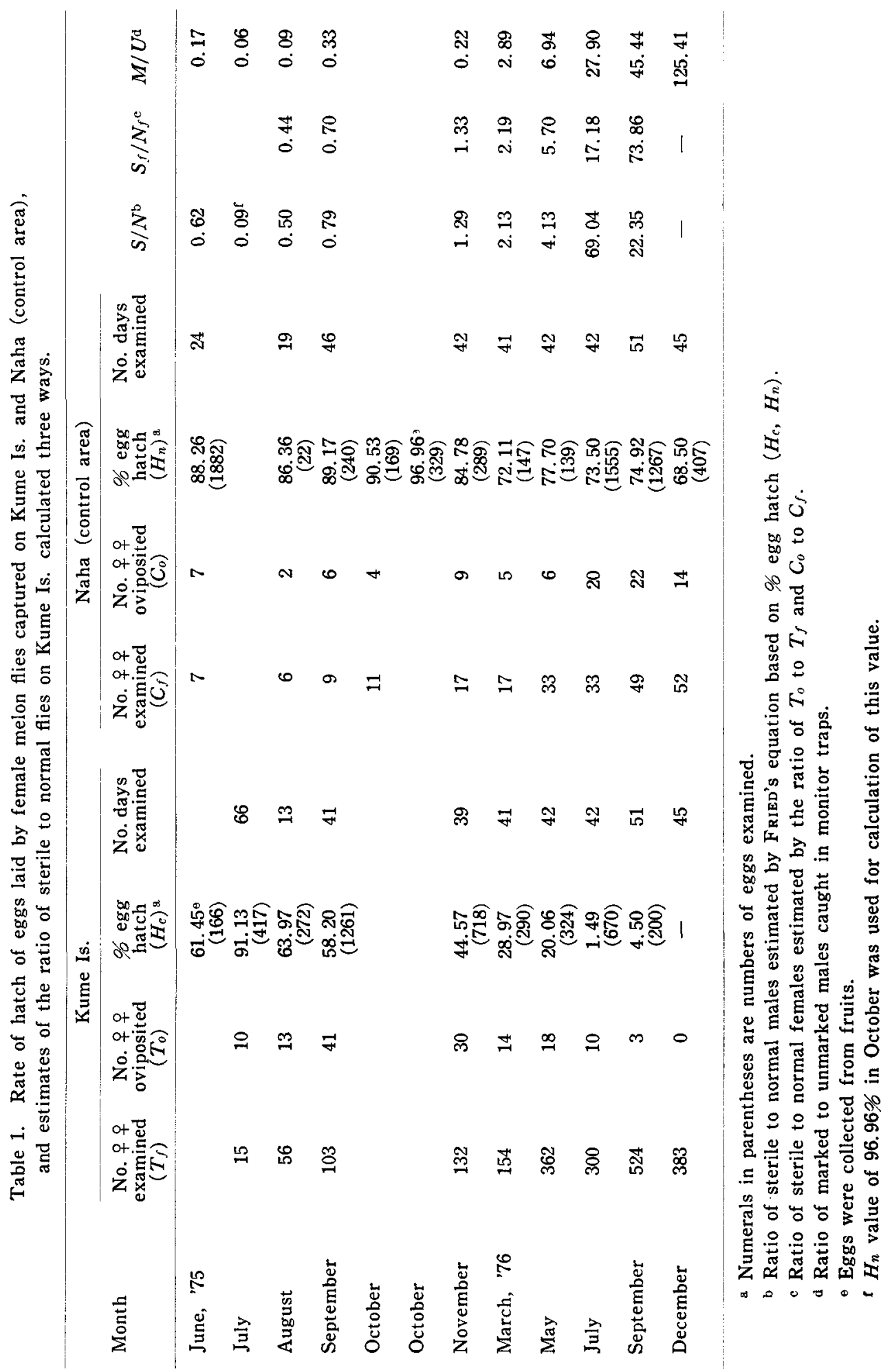


$M / U$ ratio might have been underestimated during the warm seasons. The high mortality rate of released pupae was also considered to be another cause of the decrease in the $M / U$ ratio (Fig. 2-a). However, we feel that the primary reason for the low $M / U$ ratio was the insufficient number of flies released during this period.

The $M / U$ ratio started to increase from autumn of 1975 , when the number of pupae released approached 2 million per week, exceeded 2 in February, 1976 and kept increasing in successive months until it reached 10 in June, 1976. The ratio rose to 45 in September, 1976 and exceeded 90 in October of that year. After that the values stabilized around 100 .

Fig. 2-c and columns 4 and 8 of Table 1 show the results of the experiment on hatchability of eggs laid by females collected on Kume Is. (solid circles) and at Naha, the control area (open circles). Fifteen females caught on Kume Is. in July, 1975 were examined for a total of 66 days, and 10 of these laid 417 eggs, of which $91 \%$ hatched. This value is similar to that obtained in the control area and higher than the rate obtained in the treated area in June. In August, 13 of 56 females laid 272 eggs and the percent egg-hatch decreased to 64. From September onwards, the percent egg-hatch on Kume Is. decreased consistently, that is, 58 in September, 45 in November, 29 in March, 1976, and 20 in May. In July, 1976, 10 of 300 females examined for a total of 42 days laid $670 \mathrm{eggs}$, of which $1.5 \%$ (10 eggs) hatched. In September, only 3 of 524 females, examined for a total of 51 days, laid 200 eggs, and 9 of these hatched $(4.5 \%)$. Although percent egg-hatch was higher in September than in July, this may have been due to sampling errors related to the very small number of females which laid eggs. In December we were unable to obtain a value for percent egg-hatch on Kume Is., since 383 females examined for a total of 45 days laid no eggs.

As mentioned above, detection of marked flies under an ultraviolet lamp became difficult during the warm seasons in 1975 due to the occurrence of natural fluorescence. To overcome this problem, ITô and Iwahashi (1976) presented a method to estimate the ratio of sterile to normal males based on percent egg-hatch. Their method uses FRIED's equation (FRIED, 1971), which was desinged to estimate the 'sexual competitiveness' of sterile males, $C$, at a given ratio of sterile to normal males, that is,

$$
C=\frac{H_{n}-H_{c}}{H_{c}-H_{s}} \cdot N
$$

where

$H_{n}=\%$ egg-hatch in matings of $N \sigma^{\top} \sigma^{\top} \times N$ 우 우

$H_{s}=\%$ egg-hatch in matings of $S_{\sigma^{\top}} \sigma^{\top} \times N$ 우우

$H_{\sigma}=\%$ egg-hatch at a given ratio of $S_{\sigma^{\top} \sigma^{\top}}$ to $N_{\sigma^{\top}} \sigma^{\top}$ in the presence of $N$ 우우.

$N=$ Number of normal males.

$S=$ Number of sterile males. 
$H_{s}$ is zero in our experiment when an irradiation dose of 6-7 kR was applied to pupae 2 or 3 days before adult eclosion. If we know $H_{n}, H_{c}$ and $C$, we can estimate the ratio of sterile to normal males $(S / N)$ from Eq. 1 , that is,

$$
\stackrel{S}{N}=\frac{H_{n}-H_{c}}{H_{e}} \cdot \frac{1}{C^{-}}
$$

For the value of $C, 0.7$ was tentatively used, based on the results of laboratory experiments on sexual competitiveness of irradiated melon flies (TERUYA and Zukeyama, 1975). Substituting values of percent egg-hatch on Kume Is. for $H_{c}$ and those in the control area for $H_{n}$, estimated values of $S / N$ were calculated (10th column of Table 1). The values thus obtained were higher than $M / U$ during the warm season in 1975 .

Teruya and Zukeyama (in preparation) showed that females irradiated at 6-7 $\mathrm{kR}$ are infecund. Thus, we can also estimate the ratio of sterile to normal females based on the ratio of females which oviposited (including both fertile and sterile eggs) to the total number of females collected on Kume Is. and Naha.

That is,

$$
R=C_{f} / C_{o}
$$

and

$$
\frac{S_{y}}{N_{f}}=\frac{T_{y}-R T_{0}}{R T_{a}}
$$

where

$S_{f}=$ Number of sterile females in treated area.

$N_{f}=$ Number of normal females in treated area.

$C_{f}=$ Number of females collected in control area.

$C_{a}=$ Number of females collected in control area and which oviposited eggs.

$T_{f}=$ Number of females collected in treated area.

$T_{0}=$ Number of females collected in treated area and which oviposited eggs.

Substituting values shown in Table 1 for $T_{f}, T_{o}, C_{f}$ and $C_{o}$ in Eq. 4, expected values of $S_{f} / N_{f}$ can be obtained (11th column of Table 1). If the actual ratio of sterile to normal flies is not different between sexes, $S_{f} / N_{f}$ can be used also as an index indicating the ratio of sterile to normal males, and can be compared directly with estimated values of $S / N$ and $M / U$. As shown in Table 1 , the values of $S_{f} / N_{f}$ were nearly equal to those of $S / N$, but higher than those of $M / U$ during the warm season in 1975. These three values agreed well in March and May, 1976, when the natural fluorescence disappeared. The large difference among these values in July and September was probably due to sampling error in $T_{o}$ and $H_{c}$ and also to underestimation of the $M / U$ ratio (see below).

Fig. 3 shows changes in percent infestation of fruits of $B$. laciniosa by the melon fly before, and during, the mass-releases on Kume Is. If it can be assumed that the percent infestation of fruits reflects the density of the melon fly population even when the density of the fly population is very low, percent infestation can be presented 


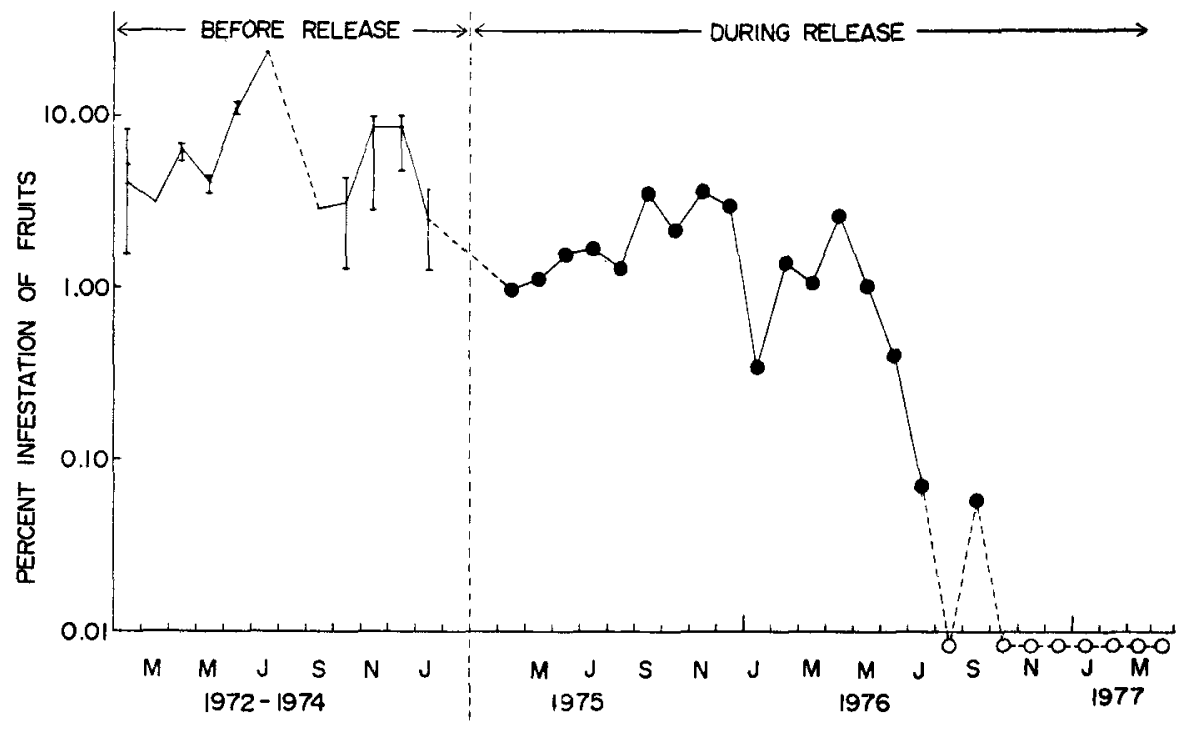

Fig. 3. Percent infestation of wild cucurbit fruits, Bryonopsis laciniosa, on Kume Is. before and during the mass-releases of sterile insects.

with a logarithmic scale such as shown in Fig. 3. The mean percentage of infested fruits in the pre-release period (from June, 1972 to January, 1975) ranged from 2.56 to 23.62. During the first year or so of the SIRM program, the percent infestation was low, fluctuating between about 3.9 to $0.4 \%$, but there was no sign of remarkable decrease. After May, 1976, however, it decreased rapidly and reached zero in August. In Septembr, when 5081 fruits were examined, the percent infestation rose to 0.06 . From October, 1976 to April, 1977, a total of 73,788 fruits of B. laciniosa was gathered on Kume Is. and examined in Naha, but there was no sign of melon fly. infestation during these seven months.

Fig. 4 shows changes in the number of wild melon fly males caught in 50 monitor traps on Kume Is. (solid circles) and those in five traps in the control area at Naha (Open circles; cited from Yamauchi et al., 1976). Traps distributed on Kume Is. caught both marked and unmarked flies during the SIRM project, the latter were counted as wild males. It is noted that after the beginning of the SIRM the number of unmarked flies on Kume Is. had increased.

In April, 1975 the number of unmarked flies on Kume Is. was 405 per 1,000 trap-days. This density was ten times higher than that recorded in February, when mass-releases were initiated, and nearly the same as that obtained before suppression. Although the numbers of melon flies caught in traps at Naha were always higher than those on Kume Is., populations at both locations fluctuated in the same manner from August, 1975 to July, 1976. After July, 1976, the melon fly population on Kume Is. began to decrease, in spite of the fact that the population in the control area was 
increasing. This suggests that the suppressive effect of mass-releases had reached a level which was sufficient to decrease the population of the next generation. As mentioned earlier, there was no sign of infestation of fruits by the melon fly on Kume Is. since October, 1976. However, unmarked flies were still found in monitor traps, probably due to the fact that marking of flies with fluorescent dye powder was not perfect. In February, 1977 the number of unmarked flies decreased to 4.2 per 1,000 trap-days. This value was about $0.4 \%$ of the peak density, however, for the abovementioned reason, it is considered to be an overestimation of the wild fly density.

\section{Discussion}

As mentioned earlier, ITô et al. (1974) estimated that the number of male flies inhabiting Kume Is. in the peak season of 1972 was about 2.5 million. It was also estimated that the fly population decreased to about $5 \%$ of the peak season density, following the application of control treatment (IWAHASHI et al., 1975). We initially released 1 to 1.5 million pupae per week. The releases made from February to July, 1975 were not sufficient to control the wild melon fly population on Kume Is. After September, 1975, pupal releases were increased to 1.5-2 million per week. As a result, the ratio of $M / U$ began to rise and percent egg-hatch began to decrease. In spite of this decrease in the percent egg-hatch, percent infestation of cucurbit fruits did not decrease markedly during the same period. These results suggest that a decrease in egg-hatch to about $30 \%$ was not enough to reduce the density of the next generation of D.cucurbitae. Actually, the numbers of unmarked flies on Kume Is.

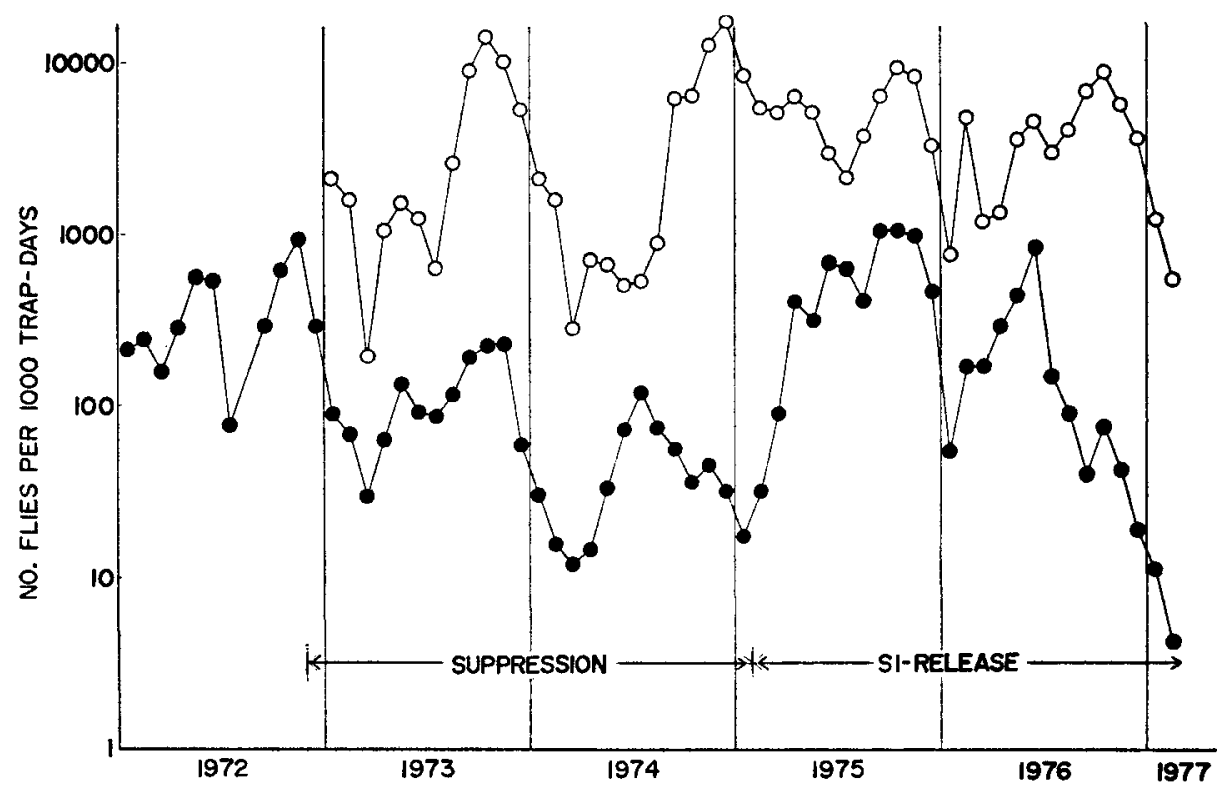

Fig. 4. Monthly changes in abundunce of male melon flies caught in 50 monitor traps on Kume Is. (solid circles) and in 5 ones in Naha, control area (open circles). 
and those in the control area fluctuated in the same manner in the latter half of 1975 (Fig. 4).

Based on studies with a model of the SIRM process for the melon fly, ITô (in preparation) suggested that releases of 4 million sterilized pupae per week could remarkably accelerate the eradication process on Kume Is. From February, 1976 we increased the number of pupae released per week, and, in May and subsequent months it reached 3.5-4 million per week. The ratio of $M / U$ increased remarkably after February. This ratio increase was less due to a decrease in the wild melon fly population as to the increase in the number of flies released (the first half of 1976 in Fig. 4). When the number of pupae released reached the maximum level of 3.5 to 4 million per week since May, a further increase in the $M / U$ ratio was recorded.

From Fig. 4 we can see that the population in the control area increased after July, 1976, while that on Kume Is. was on the decrease. At the same time, a remarkable decrease in the percent egg-hatch took place. These results suggest that our mass-releases started to suppress and reduce the wild fly population on Kume Is. since July, 1976. The sharp reduction of percent infestation of host fruits took place from May, 1976 onward (Fig. 3). This rapid decrease started from May, 1976 when the $M / U$ ratio reached about 7 and the rate of egg-hatch decreased to $20 \%$. Twenty to thirty percent in the rate of egg-hatch during peak population season may be a critical point for the success of an eradication project with SIRM.

During the SIRM program on Kume Is., all flies released were marked with a fluorescent dye powder. The monitor traps on Kume Is. thus caught both marked and unmarked flies. As mentioned previously, we recorded as marked only those flies which showed unmistakable fluorescence. It was considered that the $M / U$ ratio was always lower than the actual ratio of sterile to normal flies. That is to say, the number of unmarked flies caught in monitor traps during the SIRM was always larger than the true number of wild males. The $M / U$ value reached a constant level around 100 from October, 1976 onward. This could mean that marking with fluorescent dye was not complete or some flies lost their dye before they were trapped. If we assume that $99 \%$ of the released flies were properly marked on the ptilinum, the $M / U$ would never exceed 100 even when the population had been eradicated.

Since we do not have data on the percent of marked released flies in those months when the number of unmarked flies caught in monitor traps on Kume Is. began to decrease, we do not know exactly when the wild population began to decrease rapidly, however it was probably 1 or 2 months earlier than July, 1976. We consider that eradication of the melon fly population on Kume Is, with the SIRM was achieved by April, 1977.

\section{SUMMARY}

The sterile insect release method was applied to eradicate the melon fly, 
Dacus cucurbitae, from the $58.5 \mathrm{~km}^{2}$ island of Kume, in the Okinawa Islands group. Weekly releases of 1 to 1.5 million flies irradiated as pupae with 6-7 kR from a cobalt-60 source did not decrease the wild melon fly population. Releases of 1.5-2 million pupae per week made from September, 1975 to January, 1976 decreased the percent egg-hatch of females caught on Kume Is., but did not decrease the percent infestation significantly. The number of pupae released was increased from February, 1976 to accelerate the eradication process. When the number of pupae released exceeded 3.5 million per week, a rapid increase in the ratio of marked (sterile) to unmarked (wild) flies, a remarkable decrease in percent egg-hatch, and a decrease in percent infestation of fruits were observed. There has been no sign of melon fly infestation in wild cucurbit fruits from October, 1976 to the present time (April, 1977), despite the fact that more than 70,000 fruits were carefully examined. The eradication of the melon fly from Kume Is. was thus achieved by April, 1977, after the release of 264 million sterile fly pupae.

Acknowledgements: The author wishes to thank Mr. Hiroshi Zukeyama, Mr. Keiji Yasuda and Mr. Yoneo Kinjo for their field and laboratory assistance, the Gushikawa and Nakazato Village Offices for their help in field studies, and personnel of Naha Plant Protection Office, Ministry of Agriculture, who conducted fruit experiment surveys during the SIRM. Thanks are also dur to Dr. Yosiaki Itô and Mr. Kiichi Ohinata for their helpful advice and critical reading of the manuscript.

\section{REPERENCES}

Baumhover, A. H., A.J. Graham, B.A.Bitter, D. E. Hopkins, W. D. New, F.H. Dudley and R.C. Buchland (1955) Screw-worm control through release of sterilized flies. J. Econ. Ent. 48: $462-466$.

Fried, M. (1971) Determination of sterile-insect competitiveness. J. Econ. Ent. 64: 869-872.

Itô, Y., M. Murai, T. Teruya, R. Hamada and A. Sugrmoto (1974) An estimation of population density of Dacus cucurbitae with mark-recapture methods. Res. Popul. Ecol. 15: 213-222.

Itô, Y. and O. Iwaнashi (1976) A simple method to estimate the ratio of sterile to normal males based on hatchability of eggs. Appl. Ent. Zool. 11: 139-140.

Iтоि, Y. (in preparation) A model of sterile insect release for eradication of the melon fly, Dacus cucurbitae CoQuilhetr.

Iwahashi, O., R. Teruya, T. Teruya and Y. Itô (1975) Changes in abundance of the melon fly, Dacus cucurbitae Coquilletr before and after the suppression with cue-lure baits and proteinhydrolysate spray. Jap. J. Appl. Ent. Zool. 19: 232-236. (In Japanese with English summary)

IwAHASHI, O., Y. ITô and H. ZukEyama (1976) A progress report on the sterile insect releases of the melon fly, Dacus cucurbitae Coqullets (Diptera : Tephritidae) on Kume Is., Okinawa. Appl. Ent. Zool. 11: 182-193.

LaChance, L. E., C. H. Schmidt and R. C. Bushland (1967) Radiation induced sterilization. In Pest control, Biological, physical and selected chemical methods. Ed. KiLgore, W. W. and R. L. DoutT, N. Y., 147-196.

Kakihana, H., H. Nakamori and H. Sozmori (1975) Mass rearing of the melon fly, Dacus cucurbitae Coquillett. II. The inprovement of mass rearing. Okinawa Nogyo 13: 33-37. (In Japanese) 
Nakamori, H., H. Kakihana and H. Soemori (1975) Mass rearing of the melon fly, Dacus cucurbitae Coquiletr. I. Effect of rearing density on the yield and quantity of flies. Okinawa Nogyo 13: 27-32. (In Japanese)

Nakamori, H., H. Kákihana and H. Soemori (1976) Mass rearing of the melon fly, Dacus cucurbitae Coquillett. III. Mass collection of eggs. Okinawa Nogyo 14: 2-5. (In Japanese)

Steiner, R.F. (1957) Low-cost plastic fruit fly trap. J. Econ. Ent. 50: 508-9.

Yamauchi, S., O.Iwahashi and H. Zukeyama (1976) Changes in abundance of the melon fly, Dacus cucurbitae Coqulletr, in Naha. Okinawa Nogyo 14: 25-27. (In Japanese)

\section{不妊虫放飼法による久米島のウリミバエ根絶}

岩 橋統

沖縄本島の西約 $80 \mathrm{~km}$ 亿位置する面積約 $58.5 \mathrm{~km}^{2}$ の久米島でウリミバエを根䋓するために，大规模な不

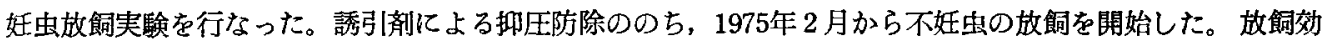
果の判定は，久米島に配置した50個のトラップに誘殺される放飼虫（放飼虫は全てマークを付してある：M) と野生虫 $(U)$ の比, 同島で採集したメスの産む卵のふ化率, 野生寄主（オキナワスズメウリ）の笴生果率 によった。1975年 2 月から 8 月までは週100〜150万匹の蛹を放飼したが，上記の示標によると放餇の効果は ほとんど現われなかった。すなわち，無防除地区のメスの産んだ卵のふ化率が 75〜90\%であったのに対し， 久米島のものでもほとんど同じレベルであった。そとで放飼数を増加し，1975年 9 月から 1976 年 1 月まで

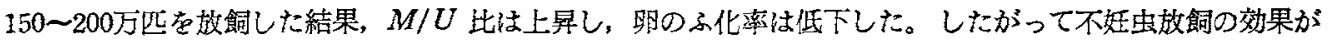
ある程度現われてきたてとが同われるが，早急に本種を根絶するにはなお不十分であると思われた。そと で，1976年 2 月以降再び放飼数を增加した。放飼数が週350万匹のレベルに達した 1976年 5 月に $M / U$ 比は 7 となり，その後も增加し続け 9 月には 90 となり，それ以後は約 100 を維持した（ $M / U$ 比がてれ以上增加 しなかったのはマークが完全でなかったととによる)。卵のふ化率は1976 年 5 月には20\%に低下した。7月 にはさらに $1.4 \%$ \%低下した（それ以後は採集したメスのはとんど全てが放飼した不妊虫となり，信賴性の あるデー夕は得られなかった。

以上のことから，久米島のウりそバエは不妊虫放飼法によって根絶したものと考光られる。なお，1975年 2 月の故飼開始時点から，1977年 3 月末までの総放飼数（蛹）は約 2 億 8 千万匹であった。 